\title{
Reticent Students in the ESL Classrooms
}

\author{
Soo R. S. (corresponding author) \\ Department of English, Faculty of Education and Social Sciences, University of Selangor, 45600 Bestari Jaya, Selangor, Malaysia \\ E-mail: sooruey@unisel.edu.my
}

Goh H. S.

The English Language and Literature Department, Faculty of Languages and Communication, Universiti Pendidikan Sultan Idris, 35900 Tanjong Malim, Perak

E-mail: goh.hs@fbk.upsi.edu.my

Doi:10.7575/aiac.alls.v.4n.2p.65

URL: http://dx.doi.org/10.7575/aiac.alls.v.4n.2p.65
Received: 02/04/2013

Accepted: 04/06/2013

\begin{abstract}
Reticence has always been regarded as a problematic phenomenon among students in the ESL classrooms. Many instructors have expressed their frustrations to decode the reticent behaviour and work out suitable strategies to help students with such behaviour. Whenever such students do not engage in the classroom discourse, they are usually regarded as not having the desire to learn or lacking in cooperation. These explanations seem simplistic, bias and stereotypical. Based on a larger project on students' reticent behaviour, this study investigated the extent in which tertiary students majoring in English experience reticence in the classrooms, and examined the underlying factors of reticence. Data were obtained from 78 students utilizing the Reticence Scale-12 (RS-12) which measures the level of reticence along six dimensions: anxiety, knowledge, timing, organization, skills and memory. The findings reveal that reticent level is high among the students, and their major problems lie in affective-control and delivery.
\end{abstract}

Keywords: reticence, ESL classroom

\section{Introduction}

In the context of English as a Second Language (ESL) teaching and learning, students' verbal participation or engagement is essentially important in the classrooms. This claim complies with the conceptualization of the Communicative Language Teaching (CLT) approach of teaching English, which sees language being taught as a system for expressing meaning (Nunan, 1999). It is believed that when students engage in the classrooms with their teachers or among peers, they are compelled to be involved in the 'negotiation of meaning', that is to express and clarify their intentions, thoughts and opinions (Lightbown \& Spada, 2006). In turn, the students 'communicative competence' or what they need to know to communicate, can be developed in the classrooms (Hymes, 1972; Larsen-Freeman, 2000; Chang \& Goswami, 2011). Therefore, student oral contribution is of great importance for class participation.

Operating from the belief that verbal participation is associated with learning, students are always encouraged by their teachers to contribute to the classroom discourse, and their participation is often evaluated according to the amount and quality of their talk (Warayet, 2011). This practice has also become an evaluative benchmark for ESL teachers to reflect if they have conducted a good lesson or elicited sufficient responses from their students. Although participation may be graded in different forms, and vary substantially from one instructor to another according to the types of interactional activities and measured quality, the ultimate goal is somewhat to increase student involvement (Bean \& Peterson, 1998). Generally speaking, with teachers' encouragement and efforts, students are always expected to be able to fully contribute in the classroom discourse. Nonetheless, the ESL classroom may be a frustrating place when most students remain silent in class, and only a small proportion of them actually participate (Fritschner, 2000).

Despite the students being aware of the importance of spoken English, and knowing the fact that participation is encouraged, many teachers still experience a great deal of quietness in the ESL classroom. The students are said to remain non-participatory, quiet or behave passively. In the field of second language acquisition, this is a situation typically termed as 'reticence'. For ESL instructors, this is a kind of uncomfortable feeling as it reflects negatively on their instructional practice. Many of them, in spite of having many years of teaching, still fail to decode the reticent behaviour, and work out suitable strategies to encourage their students to contribute more to classroom discourse. This experience also prompts us to find out more about reticence since it has always been denoted a problematic attribute that would hinder the development of oral proficiency in the English language. 


\section{Conceptualization Of Reticence Construct}

Research in the field of reticence started when Gerald M. Phillips published the first article on reticence in 1965 to the field of speech communication with the notion that some individuals had difficulties with communication in various situations (Keaten \& Kelly, 2000). This first attempt has set a strong ground for communication researchers to further explore the nature of reticence in diversified contexts. This construct has undergone revisions and re-conceptualizations overtime with more revised ideas being introduced.

Phillips's original conceptualization viewed reticence as a personality and anxiety disorder. In his later work, however, he had refined this concept and emphasized on the construct description in its behavioural dimension. This move had shifted the focus away from personality-based reticence towards a description of reticent behaviour caused by problems of inadequate communication skills (Phillips, 1984, 1997). He found that the major characteristic of reticent individuals was social withdrawal or avoidance due to their feelings of ineptitude towards social communicative events and public performance. To further illustrate reticence being a communicative behaviour, he stated that "when people avoid communication because they believe they will lose more by talking than by remaining silent, we refer to it as reticence" (Phillips, 1984, p. 52). This is the first and also a more comprehensive definition given to the construct which looks into both behavioural and cognitive dimensions.

Phillips' includes two dimensions in his conceptualization of reticence: cognitive and behavioural. The behavioural dimension involves avoidance and ineptitude brought by skills deficits in rhetorical processes in the five canons of rhetoric, (invention, disposition, style, delivery and memory) and the cognitive dimension is the faulty belief system which justifies the reticent individuals' avoidance of communication (Keaten \& Kelly, 2000).

Based on Phillips' works, Keaten and Kelly (2000) reconceptualised reticence. Their newly proposed theoretical model includes a modified behavioural and cognitive dimension with an additional affective component. They advocated that "when people avoid communication because they believe it is better to remain silent than to risk appearing foolish, we refer to this behaviour as reticence" (p. 168). Keaten et al. (1999), in an earlier report, revealed that as compared to nonreticent individuals, reticent individuals possessed elevated levels of fear of negative evaluation and a heightened sensitivity to the opinions of others. Thus, individuals who are labelling as reticent have the tendency to alleviate the problem of fear by remaining silent as they are afraid of the threat of negative evaluation by others or foolishness. This claim was confirmed in a study investigated reticent learners' beliefs about reticence by Keaten et al. (2000) where the majority of reticent individuals agreed to the statement, "It is better to remain silent than to risk appearing foolish", whereas the majority of non-reticent learners disagreed with it.

The new concept of reticence represents a departure from Phillips' definition of reticent individuals as those who believed "they will lose more by talking than by remaining silent". This is based upon the research by Keaten et al. (2000) which shows that the majority of the reticent persons disagreed with this statement. Consequently, they concluded that it was a problematic definition as it failed to capture the real situation encountered by reticent individuals. Although these two definitions are distinct in terms of the attributed cause, they are deemed similar in their research focus where both look into the faulty belief system of reticent individuals.

\section{Issues Associated With Reticence}

A very common scenario experienced and observed by many language instructors in ESL classrooms is the students' reticent behaviour. The act of being silent, reluctant to participate or speak using the target language has always been considered as the main source of frustration, and failure for both instructors and students (Flowerdew \& Miller, 1995; Jackson, 2002; Zhang \& Head, 2009). It is a major obstacle for students to develop oral proficiency in the English language as compared to the development of reading and listening skills (Jenkins, 2008).

This negative behaviour or passive attitude disrupts not only instructional plan, it also makes it hard for instructors to facilitate active learning among students. As a conspicuous consequence, it restricts students from progress, and intended course learning outcomes might not be achieved. Moreover, most of the time, instructors have to struggle in exploring ways to break the uncomfortable silence in interaction in order to minimise the feeling of discombobulation. As this problem has become one of the key issues and a challenge in the field of English language teaching, many Asian ESL instructors who have encountered this phenomenon at various degrees in their classrooms, have always attempted to seek an answer to it. However, the explanations given are normally simple and rely on stereotypical characteristics of passivity or lack of cooperation (Harumi, 2001). Thus, there is an urgent need to examine this phenomenon to have a better understanding of this behaviour.

Based on relevant literature (e.g. Li \& Jia, 2006; Liu \& Jackson, 2009, Arafat, 2013), Asian students are frequently portrayed as reticent and passive in the English language classrooms with minimal or no contribution to the classroom discourse. Most of them are reported as irresponsive to their teachers or not being enthusiastic in whole-class and group discussions, which are the major activities frequently conducted in most of the English language classes. This situation will become worse if it remains unresolved for a period of time. This is because students might either wrongly perceive that the behaviour is acceptable, or it is a norm for a language classroom.

Multiple reasons of ESL students' reticence or reluctance to participate orally in class have been identified in previous studies conducted across the Asian regions. Among the common reasons reported include fear of losing face, low proficiency, negative evaluation, cultural beliefs about appropriate behaviour in classroom contexts, incomprehensible input, teacher's teaching techniques, lack of confidence, introversion, anxiety, perceived communicative competence, etc (Tsui, 1996; Li \& Jia, 2006; Jenkins, 2008; Liu \& Jackson, 2009; Xie, 2009; Li \& Liu, 2011; Delima, 2012). In 
other words, most of these studies attribute reticence to students' linguistic competence, socio-cultural, psychological, personality and pedagogical factors. Such a massive pool of data in the present literature has welcomed a debate among researchers on the real problems behind students' reticence.

The lack of relevant knowledge about reticence has caused many instructors to wrongly perceive their students' ability in the classrooms. Donald (2010) pointed out that if students do not participate in discussion or verbally share ideas, instructors will usually think that they do not have the desire to learn. This would, consequently, influence the instructors' judgement when assessing the students' language performance since many classroom evaluation of learning relies on student actions and behaviours which are easily observed and measured (Hamelock \& Friesen, 2012).

Furthermore, some ESL practitioners also perceive that reticence only happens among students with low English proficiency, but surprisingly the same phenomenon is also discovered among those with good English language proficiency. Some of the proficient learners are found rarely engaged in conversation using English, and not willing to participate in the classroom although sufficient communication opportunities are provided. For instance, Wen and Clement (2003) found discrepancy between students' high proficiency in grammar and vocabulary and deficiency in carrying out English conversations.

It is understood that ever since the current popular theoretical perspectives of Second Language Acquisition (SLA) which stress the importance of interaction and communication, as well as L2 pedagogy that values open participation in class, there is a growing expectation for verbal classroom participation in higher education. Due to this reason, many researchers and educators generally regard students who do not engage in L2 interaction orally as being passive and unmotivated (Cao, 2009). They prefer their students to participate orally, and would feel that they have a successful lesson when participation involves student talk (Warayet, 2011). However, the reality in the classroom frequently does not match the expectation, and whenever the students show reticent behaviour they will be as problematic or weak. In fact, students' learning behaviour, including their perception towards learning and other determining factors, varies from student to student, class to class or even from institution to institution. Hence, it is important to describe and measure ESL students' reticence in L2 classrooms as a complex phenomenon. Given the scarcity of research in this area, particularly in Malaysia, this study was undertaken to investigate students' reticence in ESL classrooms at the tertiary level. To achieve this aim, the following research questions guided the present study.

\section{Research questions}

1. To what extent do students who are majoring in English experience reticence in classrooms?

2. Is there a difference in reticent behaviour between male and female students? If so, what are the differences?

3. What are the problems that contribute to the students' reticence in the classrooms?

\section{Methodology}

\subsection{Study Site}

This study was conducted at a full-fledged state university located in the central region of Malaysia. The university is culturally and linguistically diverse with a population of about 12,400 students. Currently, the university offers 87 programmes under 8 faculties. The programmes offered range from foundation, diploma, bachelor degree to postgraduate level. The medium of instruction is mainly English except for courses which are conducted in other languages such as Islamic studies and early-childhood education. This research applies a case study strategy in a teacher education programme or particularly B. Ed. TESL programme. The Faculty of Education is one of the eight faculties in this university, and the TESL programme, where the current study was conducted, is offered by the Department of English Language. The case study took place in the selected classrooms (bounded system) at the faculty.

\subsection{Participants}

In the study, 78 sophomores and juniors from four intact classes majoring in the English were involved in the study. These students, aged from 21-23, are learning English as a second language. The reasons why English-majors were selected for the study are as follows:

(i) They represent a population which possess higher level of language proficiency and receive the maximum amount of instruction in English

(ii) The participating students have been studying English for at least 12 years and are in the second and third year of university education. It is expected that students at this level have developed a satisfactory level of speaking skills. Therefore, it is reasonable to choose students at this level to participate in this study.

(iii) Most of the previously conducted studies focussed on non-English major students' reticent behaviour in proficiency English classes. Moreover, only a few studies were carried out in content subject classroom situation.

\section{3 Instrument}

The present study employed the Reticence Scale-12 or RS-12 (Kelly, et al., 2007) as the data collection instrument. It is a shortened version of the Reticence Scale (Keaten, et al., 1997). The RS-12 measures the level of reticence along six dimensions (two items per dimension) of social situation reticent individuals experience in (i) feelings of anxiety, (ii) knowledge about topics, (iii) timing skills, (iv) organization of thoughts, (v) delivery skills and (vi) memory. The 12 items were measured using a 5-point Likert scale, ranging from 1 (strongly disagree) to 5 (strongly agree). Previous 
research utilizing this measure has shown it to be a reliable measure of reticence (Kelly et al., 2007). The overall Cronbach's alpha reliability coefficient of the questionnaire is 0.804 . It is relatively high and acceptable. Thus, RS-12 is a reliable instrument used to gauge students' tendency of behaving reticent in classrooms.

The development of the Reticent Scale by Keaten, et al. (1997) and later by Kelly, et al. (2007) was consistent with Phillips' (1991, cited in Keaten, et al., 1997) conceptualization of reticent person who sees himself or herself as incompetent. Phillips noted that: "When people avoid communication because they believe they will lose more by talking than by remaining silent, we refer to it as reticence" (Phillips, 1984, as cited in Keaten, et al., 2000). Phillips (1986, as cited in Keaten, et al., 1997) also notes that whether or not a person is incompetent, it is virtually impossible for him/her to perform competently if one does not believe it possible. Thus, although reticent students may not have serious language or communicative skill deficiencies, their behaviour is likely to be incompetent if they are holding a faulty belief that they cannot speak. The Reticence Scale has taken into consideration this concern.

The Reticence Scale is a more trait-like than situational instrument to measure reticence in social conversation context. This is a fundamental tool utilised to identify students with the tendency of having reticence. By identifying individuals with skill problems in social contexts or situations, this measure is useful for screening reticence for research and treatment purposes. The questionnaire or self-report allows respondents to reflect on their behaviour more generally, rather than being restricted to how they performed in a specific interaction (Keaten, et al., 1997).

\subsection{Procedure}

The instrument was administered during class at end of the May 2013 semester. The participants, from four intact classes, were informed about the purpose of the study, and assured that their responses would be anonymous. The researchers were present during the survey to offer necessary assistance. It took approximately 15 minutes for the students to complete the instrument.

\section{Findings And Discussion}

\subsection{Frequency of reticent students in ESL classrooms}

In determining the extent to which students who are majoring in English experience reticence in classrooms, the total scores obtained in RS-12 scales were calculated. As the 12 items in the scale expressed inability to participate in academic discourse based the six dimensions, the response 'Strongly Agree' was given a value of 5, the response 'Strongly Disagree' was given a value of 1, and so forth. Thus, the total score of RS-12 revealed a respondent's tendency to be reticent in class, with the higher the score indicating the less willing the student is in participating in classroom discourse based on the six identified dimensions.

In order to identify high and low reticent groups using the responses obtained from RS-12, a median split procedure was used (O'Connell, 2010). Individuals who obtained a score of above 29 are regarded as highly reticent students; whereas individuals who scored below 29 are deemed as low reticent students (O'Connell, 2010). As presented in Table 1, this procedure resulted in 60 high reticent students $(76.9 \%)$ and 18 low reticent students $(23.1 \%)$. This scoring thus illustrates that more than three quarters of the students in the classes regarded themselves as being reticent. Furthermore, the mean score (see Table 2) of 35.12 on the scale, with a median of (35.00) and a mode of (34), were all far above the scale midpoint 29. This further confirms that a vast majority of the students were experiencing a great deal of reticence in the ESL classrooms. Previous researches (Caspi, Chajut, Saporta \& Beyth-Marom, 2006; Crombie, Pyke, Silverthorn, Jones \& Piccinin, 2003) have also repeatedly found that most students do not participate or being passive in classroom discussions. For instance, Caspi et al. (2006) and Crombie et al. (2003) respectively reported that about 55\% and $64 \%$ of the students never or rarely participated in class.

Table 1. Frequency of high reticent and low reticent students $(\mathrm{n}=78)$

\begin{tabular}{lcc}
\hline Reticent score & Frequency & Percentage (\%) \\
\hline Above 29 & 60 & 76.9 \\
Below 29 & 18 & 23.1 \\
\hline
\end{tabular}

Table 2. Descriptive Statistics of RS-12 $(n=78)$

\begin{tabular}{lccccc}
\hline & Mean & $\begin{array}{c}\text { Standard } \\
\text { deviation }\end{array}$ & Median & Mode & Range \\
\hline RS-12 & 35.12 & 6.60 & 35.00 & 34 & $20-50$ \\
\hline
\end{tabular}

The above results have challenged many previously reported findings on reticence that this behaviour is largely due to learners' low language proficiency. In many of those studies (e.g. Liu \& Jackson, 2009; Tsui, 1996), the researchers claimed that the less proficient in English the students were, the less willing they were to engage in English language classrooms conversations and valued speech communication. For instance, Tsui (1996) found that most teachers would attribute their students' reticence to low English proficiency or lack of language knowledge. However, the findings of 
the present study show that advanced-level students, as compared to low proficiency students, would also experience a high level of reticence in the language classrooms.

\subsection{Gender differences in reticent behaviour}

As Table 3 shows, there is no difference between female and male students in terms of their level of reticence. The percentage of both female and male students who were reported being highly reticent in the ESL classrooms was also quite similar with $78.6 \%$ and $72.7 \%$ respectively. Only 6 male and 12 female students regarded themselves as being low reticent or not reticent. However, this seems to contradict the general view that female students tend to be more passive, speak less frequently and confidently in classrooms, as compared to male students who are more active (Caspi, Chajut \& Saporta, 2008).

In Caspi et al.'s study (2008), by calculating the number of times students spoke in the class, they found that the volume of interactions made by women is much lower than men. Their findings also indicated a significant gender difference in terms of the degree of reticence and participatory. In contrast, in the present study, the Chi-square output (Table 4) surprisingly shows that there is no significant relationship found between the two variables (gender and level of reticence) as indicated by the p-value $>0.05$. This implies that both male and female learners are equally reticent in the sample of the present study.

Table 3. A comparison of levels of reticence among students by gender

\begin{tabular}{|c|c|c|c|c|c|}
\hline & & & \multicolumn{2}{|c|}{ reticent scale score } & \multirow[b]{2}{*}{ Total } \\
\hline & & & above 29 & below 29 & \\
\hline \multirow{10}{*}{$\begin{array}{l}\text { student } \\
\text { gender }\end{array}$} & \multirow[t]{5}{*}{ male } & Count & 16 & 6 & 22 \\
\hline & & Expected Count & 16.9 & 5.1 & 22.0 \\
\hline & & $\%$ within student gender & $72.7 \%$ & $27.3 \%$ & $100.0 \%$ \\
\hline & & $\begin{array}{l}\% \text { within reticent scale } \\
\text { score }\end{array}$ & $26.7 \%$ & $33.3 \%$ & $28.2 \%$ \\
\hline & & $\%$ of Total & $20.5 \%$ & $7.7 \%$ & $28.2 \%$ \\
\hline & \multirow[t]{5}{*}{ female } & Count & 44 & 12 & 56 \\
\hline & & Expected Count & 43.1 & 12.9 & 56.0 \\
\hline & & $\%$ within student gender & $78.6 \%$ & $21.4 \%$ & $100.0 \%$ \\
\hline & & $\begin{array}{l}\% \text { within reticent scale } \\
\text { score }\end{array}$ & $73.3 \%$ & $66.7 \%$ & $71.8 \%$ \\
\hline & & $\%$ of Total & $56.4 \%$ & $15.4 \%$ & $71.8 \%$ \\
\hline \multirow[t]{5}{*}{ Total } & & Count & 60 & 18 & 78 \\
\hline & & Expected Count & 60.0 & 18.0 & 78.0 \\
\hline & & $\%$ within student gender & $76.9 \%$ & $23.1 \%$ & $100.0 \%$ \\
\hline & & $\begin{array}{l}\% \text { within reticent scale } \\
\text { score }\end{array}$ & $100.0 \%$ & $100.0 \%$ & $100.0 \%$ \\
\hline & & $\%$ of Total & $76.9 \%$ & $23.1 \%$ & $100.0 \%$ \\
\hline
\end{tabular}

Table 4. Chi-Square test on relationship between gender and level of reticence

\begin{tabular}{lccc} 
& Value & df & Asymp. Sig. (2-sided) \\
\hline Pearson Chi-Square & $.304(\mathrm{~b})$ & 1 & .581 \\
\hline
\end{tabular}

a Computed only for a $2 \times 2$ table

b 0 cells $(.0 \%)$ have expected count less than 5 . The minimum expected count is 5.08 .

Previous literatures have reported a number of distinctive findings on the differences in the level of reticence among male and female students. Whitsel (2010) stated that in some classes boys were more passive, and in other classes girls were more passive. He clarified that although there were classroom gender differences, the differences did not always benefit a single gender. The inconsistency of the results could be attributed to the differing contexts in each classroom, which include teacher factor, topic and student personality. Besides, the use of different data collection methods was also found to offer different findings on the same issue although the same participants involved in the same study. For 
instance, Patchen (2006), in a study to investigate engendering participation, he found a discrepancy between student perceptions (via interview) and the observational data.

\subsection{Reticent Students' problems in various dimensions}

The RS-12 measures reticence of six dimensions: (1) feelings of anxiety; (2) knowledge of conversational topics; (3) timing skills; (4) organization of thoughts; (5) delivery skills; and (6) memory. Two items reflected on similar aspect were crafted to tap into each dimension. If the students at least 'agreed' with the statement(s), they were said to have reticent problem(s) in the selected aspect(s) in that particular dimension. On the contrary, if they either 'disagreed' or 'strongly disagreed' with certain statements, they were deemed less reticent or not reticent under the respective dimension.

Table 5 summarises the students' responses towards twelve problems under the six reticent-related dimensions. The analysis reveals that most of the students believed that feelings of anxiety and problems in delivery skills were the major obstacles to orally respond in ESL classroom. With regard to feelings of anxiety, 53 and 48 students (which is equivalent to 68 and $61.4 \%$ ) respectively either agreed or strongly agreed that they were nervous and tense when talking in class. This finding is very much in the same vein with previous researches (Zuraidah, 2007; Liu, 2005; Jackson, 2002) that anxiety is one of the greatest contributors to university students' reticence. With the highest number of responses pointing to the problems of anxiety, it evidently manifests that most of them were having ‘communication apprehension' (McCroskey, 1984).

Table 5. Students' responses to RS-12 statements

\begin{tabular}{lcccc}
\hline Dimensions \& Items & SD\&D & UD & A\&SA \\
\cline { 2 - 5 } & $f(\%)$ & $f(\%)$ & $f(\%)$ \\
\hline
\end{tabular}

Anxiety

1. I am nervous when talking.

2. I feel tense when talking.

Delivery skills

3. I stumble over my words.

4. I muddle my words.

Memory

5. I forget what I want to say when talking.

6. I lose sight of what I want to say when talking.

Organization

7. My thoughts are disorganized.

$29 \quad(37.2)$

8. My thoughts are jumbled.

Timing

9. I wait too long to say what I want to say.

$37 \quad(47.4)$

34 (43.6)

10. I hesitate too long to say what I want to say.

Knowledge

11. I am unaware of what to say.

$48 \quad(61.6)$

$18 \quad(23.1)$

12 (15.3)

12. I am unfamiliar with what to say.

$11 \quad$ (14.1)

$10 \quad$ (12.8)

$53 \quad(68)$

$48 \quad$ (61.5)

$24 \quad(30.8)$

$10 \quad$ (12.8)

$44 \quad$ (56.4)

$16 \quad$ (20.5)

39 (50)

$29 \quad(37.2)$

$17 \quad$ (21.8)

$32 \quad(41)$

$20 \quad(25.6)$

20

(25.6)

Note: $\mathrm{SD}=$ strongly disagree; $\mathrm{D}=$ disagree; $\mathrm{UD}=$ undecided; $\mathrm{A}=$ agree; $\mathrm{SA}=$ strongly agree
$23(29.5)$

$25 \quad$ (32) 
Moreover, the problem in delivery skills was also considered by the students as one of the influencing dimensions that caused them to be reticent. As shown in Table 5, 44 students (56.4\%) responded that they stumbled while speaking, and 39 of them $(50 \%)$ had the problem to muddle their words while talking. For the dimensions of memory, timing and organization, the difference between disagreement and agreement was not huge. Although there were students who claimed that they had problems in these dimensions, it was not as serious as the former two. Lastly, since these students were highly proficient in English, the majority of them had no difficulty in conveying what they intended to say.

\section{Conclusion And Implications}

This study attempts to investigate the extent in which tertiary students majoring in English experience reticence in the ESL classrooms, gender differences in reticence, and examined the reticent problems encountered by the students. In light of the analyses and discussions presented above, several conclusions can be drawn from the results. First, concerning whether tertiary students with higher level of English proficiency would experience reticence in classrooms like their low proficient counterparts, the finding revealed that they were similar. A large majority of the students, based on the RS-12 score, self-reported themselves being highly reticent. This finding contradicts with many previous studies which claimed that students at a higher level of proficiency are less reticent than those at a lower level in various classroom activities. Additionally, both male and female students were equally reticent in the classrooms. Lastly, most students believed that the problems in the feelings of anxiety and delivery skills were the major obstacles that made them reticent.

While becoming more aware of the existence of reticence and its consequences in ESL classrooms, both teachers and students are responsible to take some measures to transform the present classrooms into a more active one. To encourage more students to engage orally, teachers must first create a relaxing, non-threatening and supportive classroom learning environment (Liu, 2005; Jackson, 2002; Tsui, 1996). Secondly, with the adoption of communicative approach in the present English language teaching practice, teachers should clearly spell out the aims of the teaching style and explain course objectives (Liu \& Jackson, 2009). With this, students would be able to understand both teachers' and students' roles in communicative classrooms. In the mean time, this could facilitate them in setting their expectations before learning takes place.

Apart from that, it is also advisable for teachers to provide various interesting topics and modes of conducting activities. This step may not only help them to inculcate a positive attitude towards the language but also more motivated to participate in learning activities. This is effective especially for general language-enrichment or proficiency subjects. As for content subjects such as specialized TESL programme courses, the topics are usually fixed. In this situation, instructors could provide those topics in advance along with suggested reading list or any materials required for the discussion of the topics. Thus, the students would be more prepared and less anxious they would become when they are required to talk. Lastly, institutions could establish a special reticence programme such as Pennsylvania State University (PSU) Reticence Program (Kelly \& Keaten, 1992; Keaten, Kelly \& Finch, 2000) to provide treatment for individuals with communication difficulties in the classrooms.

Evidently reticence is a common yet critical phenomenon in English-language classrooms across all levels of students in institutions of higher learning. Since it has been frequently denoted a problematic behaviour by many ESL/ EFL instructors, this issue ought to be studied seriously. Since the underlying factors that cause reticence can be very complex as there is no definitive cause of reticence in the classrooms, this will, in turn, makes the issue problematic for practitioners when attempting to elicit more oral response from learners (Donald, 2010). Thus, for further exploration of the topic, it needs to be addressed in a more situational-like construct in which more data from diversified perspectives could be documented.

To understand reticence better in ESL or EFL classrooms, researches which employ both quantitative and qualitative methods should be carried out with more students in different learning contexts. Apart from that, potential coping strategies (e.g. special programme to remedy reticent) to help students should also be explored in future studies. Additionally, besides the original framework of reticence, this topic could also be discussed with reference to different theoretical frameworks such as willingness to communicate (WTC), attribution theory and theory of silence. By utilizing this measure, the issue of student reticence can be investigated at a deeper level, so that more valuable insights can be obtained to enrich the present literature of reticence.

\section{References}

Arafat, H. (2013). An exploration of causes of Saudi students' reluctance to participate in the English language classroom. International Journal of English Language Education, 1(1), 17-34. doi: 10.5296/ijele.v1i1.2652

Bean, J. C., \& Peterson, D. (1998). Grading classroom participation. New Directions for Teaching and Learning, 1998(74), 33-40. doi: 10.1002/t1.7403

Cao, Y. (2009). Understanding the notion of interdependence, and the dynamics of willingness to communicate (Doctoral dissertation). Retrieved from https://researchspace.auckland.ac.nz/handle/2292/5584

Caspi, A., Chajut, E., Saporta, K., \& Beyth-Marom, R. (2006). The influence of personality on social participation in learning environments. Learning and Individual Differences, 16(2), 129-144. doi:10.1016/j.lindif.2005.07.003

Caspi, A., Chajut, E., \& Saporta, K. (2008). Participation in class and online discussions: Gender differences. Computers \& Education, 50(3), 718-724. doi:10.1016/j.compedu.2006.08.003

Chang, M., \& Goswami, J. S. (2011). Factors affecting the implementation of communicative language teaching in 
Taiwanese college English classes. English Language Teaching, 4(2), 3-12. doi:10.5539/elt.v4n2p3

Crombie, G., Pyke, S. W., Silverthorn, N., Jones, A., \& Piccinin, S. (2003). Students' perception of their classroom participation and instructor as a function of gender and context. Journal of Higher Education, 74(1), 51-76. doi:10.1353/jhe.2003.0001

Delima, E. M. (2012). A reticent student in the classroom: A consequence of the art of questioning. Asian EFL Journal, 60, 50-69. Retrieved from http://asian-efl-journal.com/

Donald, S. (2010). Learning how to speak: Reticence in the ESL classroom. The Annual Review of Education, Communication, and Language Sciences, 7, 41-58. Retrieved from http://research.ncl.ac.uk/ARECLS/index.html

Flowerdew, J. \& Miller, L. (1995). On the notion of culture in L2 lectures. TESOL Quarterly, 29(2), 345-373. doi: $10.2307 / 3587628$

Fritschner, L. M. (2000). Inside the undergraduate college classroom: Faculty and student differ on the meaning of student participation. The Journal of Higher Education, 71(3), 342-362.

Hamelock, M., \& Friesen, N. (2012). One student's experience of silence in the classroom. Retrieved from http://learningspaces.org/2012/07/13/silence/

Harumi, J. (2001, Nov). The use of silence by Japanese EFL learners. Paper presented at the JALT International Conference, Kitakyushu, Japan.

Hymes, D. H. (1972). On communicative competence. In C. J. Brumfit \& K. Johnson (Eds.), The communicative approach to language teaching (pp. 5-27). Oxford: Oxford University Press

Jackson, J. (2002). Reticence in second language case discussion: Anxiety and aspirations. System, 30(1), 65-84. doi:10.1016/s0346-251x(01)00051-3

Jenkins, J. R. (2008). Taiwanese private university EFL students' reticence in speaking English. Taiwan Journal of TESOL, 5(1), 61-93. Retrieved from http://140.119.172.17/journal/ESL/

Keaten, J. A., \& Kelly, L. (2000). Reticence: An affirmation and revision. Communication Education, 49(2), 165-177. doi: $10.1080 / 03634520009379203$

Keaten, J. A., Kelly, L., \& Finch, C. (1997). Development of an instrument to measure reticence. Communication Quarterly, 45(1), 37-54. doi: 10.1080/01463379709370043

Keaten, J. A., Kelly, L., \& Finch, C. (1999, Nov). Effects of the Penn State reticence program on beliefs about communication and fear of negative evaluation. Paper presented at the annual convention of the National Communication Association, Chicago, IL.

Keaten, J. A., Kelly, L., \& Finch, C. (2000). Effectiveness of Penn state program in changing beliefs associated with reticence. Communication Education, 49(2), 134-145. doi:10.1080/03634520009379201

Kelly, L., \& Keaten, J. (1992). A test of the effectiveness of the reticence program at the Pennsylvania state university. Communication Education, 41(4), 361-374. doi:10.1080/03634529209378898

Kelly, L., Keaten, J. A, Hazel, M., \& Williams, J. A. (2007). Effects of reticence and affect for communication channels on usage of instant messaging and self-perceived competence. Paper presented at the annual meeting of the National Communication Association, Chicago, IL.

Larsen-Freeman, D. (2000). Techniques and principles in language teaching. Oxford: Oxford University Press.

Li, H., \& Liu, Y. (2011). A brief study of reticence in ESL class. Theory and Practice in Language Studies, 1(8), 961965. doi:10.4304/tpls.1.8.961-965

Li, X., \& Jia, X. (2006). Why don’t you speak up? East Asian students' participation patterns in American and Chinese ESL classrooms. Intercultural Communication Studies, 15(1), 192-206.

Lightbown, P. M., \& Spada, N. (2006). How languages are learned ( $3^{\text {rd }}$ ed.). Oxford: Oxford University Press.

Liu, M. (2005). Causes of reticence in EFL classrooms: A study of Chinese university students. Indonesian Journal of English Language Teaching, 1(2), 220-236.

Liu, M., \& Jackson, J. (2009). Reticence in Chinese EFL students at varied proficiency levels. TESL Canada Journal, 26(2), 65-81. Retrieved from http://www.teslcanadajournal.ca/index.php/tesl

McCroskey, J. C. (1984). The communication apprehension perspective. In J. A. Daly and J. C. McCroskey (Eds.), Avoiding communication: Shyness, reticence and communication apprehension (pp. 13-38). Beverly Hills, CA: Sage

Nunan, D. (1999). Second language teaching and learning. Boston, MA: Heinle \& Heinle.

O'Connell, M. (2010). To text or not to text: Reticence and the utilization of short message services. Human Communication, 13(2), 87-102. Retrieved from http://www.uab.edu/Communicationstudies/humancommunication/

Patchen, T. (2006). Engendering participation, deliberating dependence: Inner-city adolescents' perceptions of classroom practice. Teachers College Record, 108(10), 2053-2079. Retrieved from http://www.tcrecord.org/

Phillips, G. M. (1984). Reticence: A perspective on social withdrawal. In J. A. Daly \& J. C. McCroskey (Eds.), Avoiding communication: Shyness, reticence, and communication apprehension (pp. 51-66). Beverly Hills, CA: Sage.

Phillips, G. M. (1997). Reticence: A perspective on social withdrawal. In J. A. Daly \& J. C. McCroskey, J. Ayres, T. Hopf, \& D. M. Ayres (Eds.), Avoiding communication: Shyness, reticence, and communication apprehension (2nd ed.) (pp. 129-150). Cresskill, NJ: Hampton Press.

Tsui, A. (1996). Reticence and anxiety in second language learning. In K.M. Bailey \& D. Nunan (Eds.), Voices from the language classroom: Qualitative research in second language education (pp. 145-167). Cambridge, UK: Cambridge University Press.

Warayet, A. (2011). Participation as a complex phenomenon in the EFL classroom (Doctoral dissertation). Retrieved from https://theses.ncl.ac.uk/dspace/bitstream/10443/1322/1/Warayet11.pdf

Wen, W. P., \& Clément, R. (2003). A Chinese conceptualization of willingness to communicate in ESL. Language, 
Culture and Curriculum, 16(1), 18-38. doi:10.1080/07908310308666654

Whitsel, C. M. (2010). Classroom gender differences in Tajikistan. Retrieved from http://www.irex.org/resource/classroom-gender-differences-tajikistan-research-brief

Xie, X. (2009). Why are students quiet? Looking at the Chinese context and beyond. ELT Journal, 64(1), 10-20.

Zhang, X., \& Head, K. (2009). Dealing with learner reticence in the speaking class. ELT Journal, 64(1), 1-9.

Zuraidah, A. (2007). Willing learners yet unwilling speakers in ESL. Asian Journal of University Education, 3(2), 57-

74. 